\title{
ETIKA DAKWAH DALAM AL-QUR'AN DAN HADITS
}

\author{
Khoirurroji'in \\ IAI Agus Salim Metro \\ Jl. Brigjend. Sutiyoso, No. 7, Kota Metro \\ masri.jadidah@gmail.com
}

\begin{abstract}
The concept of da'wah is not only related to the problem of how to speak effectively but also the ethics of speech. Since entering the era of reform, Indonesian society has been in a state of euphoria, free to talk about anything, to anyone, in any way. Al-Qur'an refers to speaking as one of human nature. Especially when discussing or delivering religious law. Although the edited command was edited to the Prophet, but the message contained in the verse can be generally applied to every Muslim who undertakes deliberation or preaching. It is required in the verse about the attitude that must be done to succeed in deliberation or in delivering religious law, preaching at its origin it is difficult to be accepted by the souls of infidels, when delivered in a bad way, a rude way, of course it will only make people run away from the truth (da'wah). For this reason, da'wah basically must be conveyed in a gentle way.
\end{abstract}

Keywords: Da'wah Ethics, Al-Qur'an, Hadith

\begin{abstract}
Abstrak
Konsep tentang dakwah tidak hanya berkaitan dengan masalah cara berbicara efektif saja melainkan juga etika bicara. Semenjak memasuki era reformasi, masyarakat Indonesia berada dalam suasana euforia, bebas bicara tentang apa saja, terhadap siapapun, dengan cara bagaimanapun. Al-Qur'an menyebut berbicara sebagai salah satu fitrah manusia.khususnya ketika bermusyawarah atau menyampaikan syariat agama. Walaupun secara redaksional perintah tersebut disematkan kepada Nabi saw., namun pesan yang terdapat pada ayat tersebut bisa berlaku umum bagi tiap muslim yang melakukan musyawarah atau dakwah.Diisyaratkan pada ayat tersebut mengenai sikap yang harus dilakukan untuk mensukseskan musyawarah atau dalam menyampaikan syariat agama, Dakwah yang pada asalnya susah untuk diterima oleh jiwa orang-orang kafir, ketika disampaikan dengan cara yang buruk, cara yang kasar, tentunya justru akan membuat orang semakin lari dari kebenaran (dakwah). Oleh karena itulah, dakwah pada dasarnya harus disampaikan dengan cara lemah lembut.
\end{abstract}

\section{Kata Kunci : Etika Dakwah, Al-Qur'an, Hadits}

\section{Pendahuluan}

Dakwah secara harfiyah berarti mengajak atau menyeru. ${ }^{1}$ Dakwah merupakan salah satu dari istilah keagamaan yang telah banyak disalah gunakan baik fungsi maupun hakikatnya. Terlebih ketika kata atau istilah tersebut telah menjadi bagian bahasa Indonesia yang dibakukan dan mempunyai makna beragam dalam kamus bahasa Indonesia misalnya, kata dakwah diartikan

1 Enjang AS dan Aliyudin, Dasar-Dasar Ilmu Dakwah, (Bandung: Widya Padjadjaran, 2009), h. 3. Ibid, h. 4. 
antara lain prepaganda yang mempunyai konotasi positif dan dan negatif. ${ }^{2}$ Sementara dakwah dalam istilah agama Islam konotasinya selalu tunggal dan positif. Yakni mengajak kepada peningkatan ibadah dan pengabdian pada sang khaliq (dalam arti luas). Bahkan dalam Alquran dan Sunnah merupakan bagian dari prinsip ajaran yang diwajibkan.

Dari realita dan fakta yang ada, temyata pergeseran makna dakwah hingga mempunyai dua konotasi tidak sedikit disebabkan oleh etika para dainya. Antara lain banyaknya dai yang menempatkan dirinya pada bidang yang bertolak belakang dengan inti maupun substansi dakwah sendiri. Dalam membahas etika dakwah terdapat dua dasar atau landasan yang dijadikan pijakan utama yaitu Al-Qur'an dan Al-Hadits.

\section{Etika dakwah Menurut Al-Quran}

Etika ditinjau dari segi bahasa berasal dari bahasa Yunani yaitu ethos yang berarti adat kebiasaan. ${ }^{3}$ Dalam kamus besar bahasa Indonesia, kata etika diartikan sebagai ilmu tentang apa yang baik dan apa yang buruk atau ilmu tentang hak dan kewajiban moral (akhlak). ${ }^{4}$ Dalam batasan pengertian itu maka etika bisa duniawi dan bisa ukhrawi.Sebab baik buruknya sesuatu masih perlu bahasan tertentu.Misalnya di mata Si A baik belum tentu di mata Si B.

Sementara pada makna yang kedua, yakni tentang hak dan kewajiban moral ${ }^{5}$ meski perlu diurai lebih luas. Namun konotasi umum lebih cenderung kepada "keagamaan".Secara khusus bila dikaitkan dengan konteks dakwah.

Sedangkan secara terminologis, menurut Ahmad Amin, bahwa etika berarti ilmu yang menjelaskan arti baik dan buruk, menyatakan tujuan yang harus dituju oleh manusia di dalam perbuatan mereka, dan menunjukan jalan yang seharusya diperbuat. ${ }^{6}$ Secara lebih spesifik, Ki Hajar Dewantara mengartikan etika, sebagai ilmu yang mempelajari soal kebaikan dan keburukan dalam kehidupan manusia, terutama yang berkaitan dengan gerak-gerik pikiran dan rasa yang merupakan pertimbangan dan perasaan, sehingga dapat menyampai tujuannya dan bentuk perbuatan. ${ }^{7}$

Dengan demikian, pembahasan mengenai etika adalah perkiraan sistematis yang berusaha mengerti mengapa, atau atas dasar apa kita harus hidup menurut norma-norma tertentu. Dapat juga diartikan sebagai ilmu yang membicarakan tentang baik dan buruk. Dan tentang hak dan kewajiban moral (akhlak). Hal demikian senada dengan pemahaman Mafri Amir yang menyatakan bahwa etika merupakan pencerminan dari pandangan masyarakat mengenai yang baik dan yang buruk, serta membedakan perilaku yang dapat

2 Ibid, h.4.

3 Hamzah Ya'qub, Etika Islam Pembinaan Akhlak aI-Karimah, Cet. V, (Bandung: Diponegoro,1996), h. 12.

4 Tim Penyusun Kamus Pusat Bahasa, Kamus Bahasa Indonesia, (Jakarta Pusat Bahasa, 2008), h.402

5 Ibid

6 Ahmad Amin, Etika Ilmu Akhlak, Cet. V, (Jakarta: Bulan Bintang, 1996), h. 3.

7 Abudin Nata, Akhlak Tasawuf(Jakarta: Bulan Bintang, 1996), h. 88. 
diterima dengan yang ditolak guna mencapai kebaikan dalam kehidupan bersama. ${ }^{8}$

Selanjutnya dalam konteks dakwah, etika dapat dipandang sebagai sarana orientasi bagi usaha da'i untuk menjawab pertanyaan fundamental mengenai "bagaimana harus hidup dan bertindak"

Dari pengertian tadi semakin jelas bahwa kajian atas dituju tinjauan kita berkenaan dengan etika dakwah adalah moral umum dalam batasan agama, apa dan bagaimana seharusnya suatu etika dakwah tersosialisasi dalam pribadi da'inya secara khusus dan pada lembaganya secara umum.

Di dalam al Qur'an telah diterangkan mengenai, bagaimana etika dakwah para dai dalam kegiatan berdakwah? Diantaranya etika dakwah yang diterangkan yaitu ikhlas (QS. al Bayyinah : 5), konsisten antara ucapan dan perbuatan (QS ash Shaff: 2-3), lemah lembut (QS Ali Imran: 159), dan takut kepada Allah (QS al Mu'minuun: 57-61). Selanjutnya akan kita kaji secara lebih mendalam dari tafsir ayat-ayat tersebut.

\section{Ikhlas dalam Berdakwah}

Ikhlas dalam berdakwah berarti tidak menghitung-hitung hasil dakwah kita dengan segala bentuk imbalan duniawi: materi, pengaruh, nama besar, popularitas, dukungan massa, dan sebagainya. Dari dakwah yang ikhlas, kita hanya boleh berharap Allah swt melimpahkan hidayah kepada ummat yang kita dakwahi, melalui ikhtiar optimal yang kita lakukan.Kita hanya boleh berharap mereka yang kita dakwahi menjadi orang-orang berkepribadian islami, dan turut bersama-sama memperjuangkan kalimat Allah. Sebagaimana Allah berfirman dalam QS al Bayyinah:5

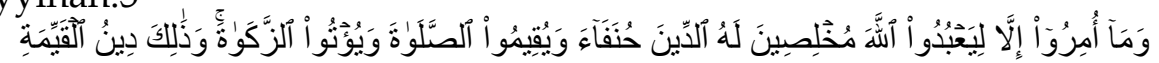

Padahal mereka tidak disuruh kecuali supaya menyembah Allah dengan memurnikan ketaatan kepada-Nya dalam (menjalankan) agama dengan lurus, dan supaya mereka mendirikan salat dan menunaikan zakat; dan yang demikian itulah agama yang lurus.

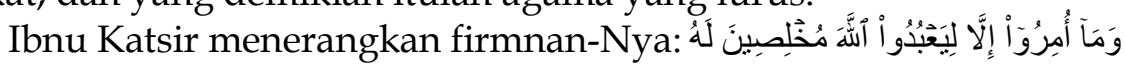

(Padahal mereka tidak disuruh kecuali supaya menyembah Allah dengan memurnikan ketaatan kepada-Nya dalam (menjalankan) agama dengan lurus.

Selaras dengan firman-Nya QS Al Anbiyaa: 25

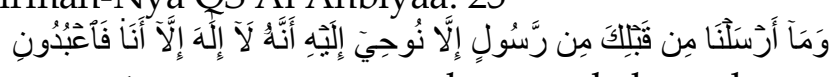

Dan Kami tidak mengutus seorang rasulpun sebelum kamu, melainkan Kami wahyukan kepadanya: "Bahwasanya tidak ada Tuhan yang hak melainkan Aku, maka sembahlah olehmu sekalian akan Aku".

Sedangkan kata khunafaa berarti lurus, yakni lurus kepada tauhid dari syirik. Allah berfirman: An Nahl: 36

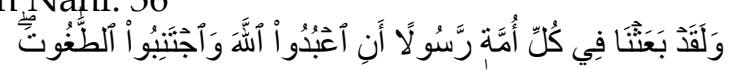

Dan sesungguhnya Kami telah mengutus rasul pada tiap-tiap umat (untuk menyerukan): "Sembahlah Allah (saja), dan jauhilah Thaghut itu. 
Firman-Nya: mendirikan salat yakni lebih utamanya ibadah badan, menunaikan zakat,yakni menyantuni para faqir dan orang yang membutuhkan pertolongan. ${ }^{9}$

Mengenai kata din al-qayyimah. Kata din berarti agama, yang terambil dari kata dana-yadinu-dinan, yang berarti patuh, rendah dan tunduk terhadap ajaran agamanya serta merasa rendah dihadapan Tuhannya.

Kata al-qayyimah terambil dari qama-yaqumu-qauman, qaumatan, qiyaman, qamatan, yang berarti berdiri tegak lurus. Kata tersebut digunakan dalam berbagai makna, namun kesimpulan maknanya adalah sempurna dan memenuhi semua kriteria yang diperlukan.

Dengan demikian, maka makna dinul-qayyimah adalah agama yang sangat lurus dan sangat sempurna. Kata ini hanya satu kali disebutkan dalam Al-quran, yaitu pada surah al-Bayyinah ayat 5. Sedangkan kata yang seakar dengannya yaitu ad-dinul-qayyim disebutkan 3 kali dalam Al-quran, yaitu pada surah at-Taubah / 9:36,arum /30:30 dan 4310

Dalam Kamus Al Munawwir, ikhlas diartikan mumi, tidak keeampuran. "Sebagaimana ayat di atas, kita diperintahkan unutk memurnikan ketaatan kepada Allah serta tidak melalaikan tindak kemusyrikan. Dalam kaitan dengan dakwah, dalam perkembangannya ikhlas diartikan sebagai sebuah ketulusan hati. ${ }^{11}$ Sehingga ikhlas menjadi landasan etika bagi para dai dalam melaksankan kegiatan dakwah. Jadi, kegiatan berdakwah tanpa mengharap imbalan dalam bentuk apapun, dimana Allah akan membalas pahala dengan surganya. Dari Amirul Mukminin, Umar bin Khathab ra, ia berkata,

"Aku mendengar Rasulullah saw. bersabda, "Sesungguhnya segala amal perbuatan bergantung kepada niatnya dan tiap orang akan mendapatkan apa yang ia niatkan Barang siapa yang hijrahnya kepada Allah dan RasulNya, maka ia akan mendapatkan pahala hijrah karena Allah dan Rasulullah. Barang siapa yang hijrahnya kw'ena faktor duniawi yang akan ia dapatkan atau karena wanita yang akan ia nikahi, maka ia dalam hijrahnya itu ia hanya akan mendapatkan apa yang ia niatkan "(HR Bukhari-Muslim) ${ }^{12}$

Kini, kata ikhlas yang sesungguhnya mulia itu telah banyak ditawar oleh segolongan manusia dengan tapi. Kita merasa sedih mendengar demikian banyak da'i mengedepankan ketidak ikhlasan dengan segala embeI-embel yang menjadi tujuannya. Kita melihat begitu marak juru dakwah tampil di mimbar maupun media dengan mengedepankan performa lahiriah, semata berbekal penampilan fisik dan unik yang menjual. Seperti halnya, mungkin Anda pemah ditolak

${ }^{9}$ Ismail Ibnu Katsir, Tafsir Ibnu Katsir, Juz VII, (Mesir: Maktabah sh-Shofa, 2004), b. 285.

10 Departemen Agama RI, Al Qur'an dan Terjemahya, Jilid l, (Jakarta: Departemen Agama RI, 2009), h. 737.

11 Ahmad Warson Munawwir, Kamus Arab-Indonesia, (Surabaya: Pustaka Progresif; 1997), n 359 .

12 Abu Zakaria Yahya bin Syaraf al Nawawi, Riyadhus Sholihin, (Surabaya: Al Hidayah l"I’im Penyusun Kamus Pusat Bahasa, Op.Cit, h. 803. 
ketika meminta beberapa orang da'i untuk berceramah di masjid pelosok, hanya karena da'i itu sudah berbeda level keda'iannya.

\section{Konsisten antara Ucapan dan Perbuatan dalam Berdakwah}

Orang yang beramal tanpa konsistensi dapat digambarkan sebagai orang yang telah menanam tetapi tidak merawat sehingga amalnya layu, kurus kering, hancur diserang dosa, atau bahkan habis musnah sehingga ketika datang saatnya menghadap Allah, ia kebingungan karena tidak satu bulir pun pahala bisa dipetiknya.

Dalam Kamus Bahasa Indonesia, konsisten diartikan selaras, sesuai yakni antara perbuatan dengan ucapan."Mengenai konsisten dalam berdakwah, Allah berfirman dalam QS Ash Shaff: 2-3

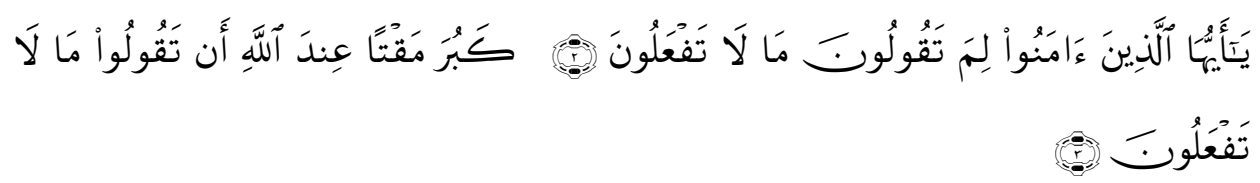

Artinya:

"Hai orang-orang yang beriman, mengapa kamu mengatakan apa yang tidak kamu perbuat?.Amat besar kebencian di sisi Allah bahwa kamu mengatakan apa-apa yang tiada kamu kerjakan."

Kata( مَتقنًا yang amat sangat dari Allah. Perbuatan yang sangat dimarahi-Nya itu adalah zina dan ucapan yang tidak diusahakan pelaksanaanya dengan perbuatan.

Asbabun nuzul ayat di atas menurut riwayat dari "Abdullah bin Salam, ia berkata," beberapa sahabat Nabi saw mengajak kami duduk kemudian kami berkata,'jika kami tahu perbuatan apa yang telah disukai Allah kami pasti melakukannya,' maka turunlah ayat 1-4 surah as-Saff.

Allah swt mengingatkan kaum muslimin akan kekurangankekurangan yang ada pada mereka, yaitu mereka mengatakan suatu perkataan, tetapi mereka tidak merealisasikan atau mengerjakannya. Di antaranya mereka berkata,"kami ingin mengerjakan kebajikan-kebajikan yang diperintahkan Allah, tetapi jika datang perintah itu, mereka tidak mengerjakannya.

Ada dua macam kelemahan manusia yang dikemukakan ayat ini, yaitu:

1. Ketidaksesuaian antara perkataan dan perbuatan mereka. Kelemahan ini kelihatannya mudah untuk diperbaiki, tetapi sukar dilaksanakan. Sangat banyak manusia yang pandai berbicara, suka menganjurkan suatu berbuatan baik, dan mengingatkan agar orang lain menjauhi larangan larangan Allah tetapi ia sendiri tidak melaksanakannya. Diriwayatkan oleh Ibnu 'Abbas bahwa "Abdullah bin Rawahah berkata: para mukmin pada masa Rasulullah sebelum jihad diwajibkan berkata," seandainya kami mengetahui perbuatan-perbuatan yang disukai Allah ialah beriman kepadaNya, berjihad menghapuskan kemaksiatan yang dapat merusak iman, dan mengakui kebenaran 
risalah yang disampaikan Nabi-Nya."Setelah datang perintah jihad, sebagian orang-orang yang beriman merasa berat melakukannya. Maka turunlah ayat ini sebagai celaan akan sikap mereka yang tidak baik itu.

2. Tidak menempati janji yang telah mereka buat. Suka menempati janji yang telah ditetapkan merupakan salah satu ciri dari ciri-ciri orang-orang yang beriman. Jika ciri itu tidak dipunyai oleh orang yang mengaku beriman kepada Allah dan rasul-Nya, berati ia telah menjadi orang yang munafik.

Ibnu Katsir dalam tafsirya, mengaitkan ayat di atas sebagai diantara tanda-tanda orang munafik, sebagaimana Rasulullah saw bersabda:

Tanda-tanda orang muanik ada tiga; ketika berjanji mengingkari, ketika berkata bohong, dan ketika dipercaya berkhianat. (HR Shahihain)"

Namun tidak berarti bahwa orang-orang tidak boleh mengatakan kebenaran bila ia sendiri belum mampu melaksanakannya. Mengatakan kebenaran wajib, sedangkan melaksanakannya tergantung kemampuan. Allah berfirman At Taghabun / 64:16

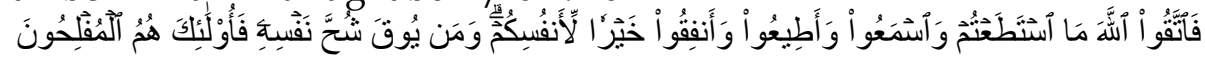

Allah memperingatkan bahwa sangat besar dosanya orang mengatakan sesuatu, tetapi ia sendiri tidak melaksanakannya. Hal ini berlaku baik dalam pandangan Allah maupun dalam pandangan masyarakat.

Menempati janji merupakan perwujudan iman yang kuat. Budi pengerti yang agung, dan sikap yang berprikemanusiaan pada seseorang, menimbulkan kepercayaan dan penghematan masyarakat. Sebaliknya, perbuatan menyalahi janji tanda iman yang lemah, serta tingkah laku yang jelek dan sikap yang tidak berkemanusiaan, akan menimbulkan saling mencurigai dan dendam di dalam masyarakat. Oleh karena itulah, agama islam sangat mencela orang yang suka berdusta dan menyalahi janjinya.

Agar sifat tercela itu tidak dipunyai oleh dai dan orang-orang beriman, alangkah baiknya jika menepati janji dan berkata benar itu dijadikan tujuan pendidikan yang utama yang diajarkan kepada anakanak disamping beriman kepada Allah dan rasul-Nya dan melatih diri mengerjakan berbagai bentuk ibadah yag diwajibkan.

\section{Lemah Lembut dalam Berdakwah}

Tauladan Kita Nabi Muhammad saw terhadap seorang yang belum mengerti Allah berfirman dalam QS Ali Imran: 159

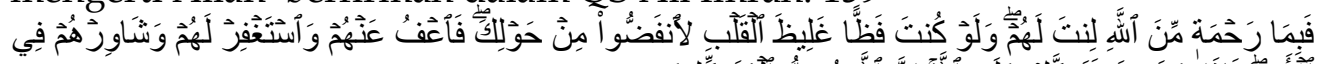

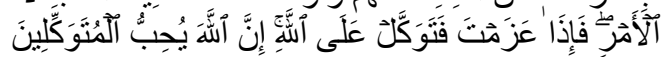

Maka disebabkan rahmat dari Allah-Iah kamu berlaku Iemah-Iembul terhadap mereka.Sekiranya kamu bersikap keras lagi berhati kasar, tentulah mereka menjauhkan diri dari sekelilingmu.Karena itu maafkanlah mereka, mohonkanlah ampun bagi mereka, dan bermusyawarahlah dengan mereka dalam urusan itu.Kemudian apabila kamu telah membulatkan tekad, maka 
bertawakallah kepada Allah.Sesungguhnya Allah menyukai orang-orang yang bertawakal kepada-Nya.

Ibnu Katsir menerangkan ayat di atas bahwa Allah swt berfirman kepada rasul-Nya seraya menyebutkan anugerah yang telah dilimpahkanNya kepada dia, juga kepada orang-orang mukmin, yaitu Allah telah membuat hatinya lemah lembut kepda umatnya yang akibatnya mereka mentaati perintahnya dan menjauhi larangnya, Allah juga membuat tutur katanya terasa menyejukkan hati mereka." 13

\section{Takut kepada Allah dalam Berdakwah}

Allah berfirman dalam QS al Mu'minuun: 57-61

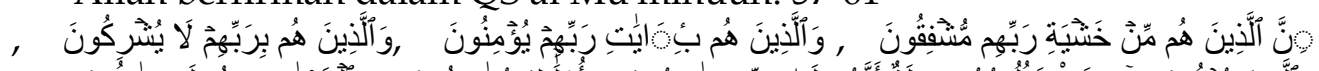

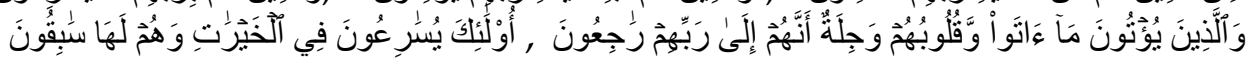

Sesunguhnya orang-orang yang berhati-hati karena takut akan (azab)

Tuhan mereka Dan orang-orang yang beriman dengan ayat-ayat Tuhan mereka Dan orang-orang yang tidak mempersekutukan dengan Tuhan mereka (sesuatu apa pun). Dan orang-orang yang memberikan apa yang telah mereka berikan, dengan hati yang takut, (karena mereka tahu bahwa) sesungguhnya mereka akan kembali kepada Tuhan mereka. mereka itu bersegera untuk mendapat kebaikan-kebaikan, dan merekalah orang-orang yang segera memperolehnya.

Kata musyfiqun bentuk jamak dari lafal musyfiq yang terambil dari kata .syafaqa yaitu bercampumya cahaya siang hari dengan gelapnya malam seiring dengan terbenamnya matahari. Allah swt bersumpah dalam allnsyiqaq:16, "Fala uqsimu bi a.sy-syafaq" (Maka sesungguhnya Allah bersumpah dengan cahaya merah di walau senja). Dari lafal syafaqa lahir kata isyfaq yang berarti perasaan kasihan yang bercampur antara takut dan simpati. Seorang musyjik (yang merasa kasihan) menyayangi musyfaq 'alaih (yang dikasihi) dan merasa takut sesuatu yang tidak diinginkan teljadi padanya. Jika lafal asyfaqa diikuti oleh huruf mim maka menunjukkan perasaan takut lebih dominan, sedangkan jika diikuti dengan huruf Fi maka rasa kasihan lebih besar, Dalam ayat ini di jelaskan tuduhan orang-orang kafir bahwa para malaikat adalah anak-anak Allah sangatlah keliru dan salah, karena sesungguhnya para malaikat adalah hamba-hamba Allah yang mulia, yang selalu berhati-hati karena merasa takut dan senantiasa patuh serta tunduk kepadaNya ${ }^{14}$

Pada ayat-ayat yang lalu (al Mu'minuun: 51-56), Allah mencela perbuatan orang-orang kafir yang menyeleweng dari agama tauhid yang murni dan terpecah belah beberapa golongan, masing-masing golongan menganggap bahwa golongannyalah yang benar sehingga mereka menyangka bahwa apa yang mereka capai di dunia berupa kekayaan dan anak keturunan yang banyak, adalah karena Allah telah meridai agama mereka, maka pada ayat-ayat berikut ini Allah menerangkan pula sifat-sifat orang-orang mukmin yang terpuji yang tetap berpegang teguh kepada keyakinan yang benar yaitu agama tauhid.

13 Ismail, lbnu Katsir, Juz 1l, h. 89.

14 Departemen Agama Rl, Op.Cit. Jilid 6 
Salah satu sifat-sifat orang yang benar-benar beriman itu pertama ialah takut kepada Tuhan. Karena itu mereka selalu mencari keridaan-Nya. Yang menjadi pedoman bagi hidup mereka adalah ajaran agama karena ajaran itulah prinsip mereka. Apa yang bertentangan dengan prinsip-prinsip itu tetap mereka tolak bagaimana pun akibatnya. Iman mereka tidak dapat digoyahkan oleh bujuk rayu atau ancaman apapun.

Sifat yang kedua ialah percaya sepenuhnya kepada bukti-bukti Keesaan dan kekuasaan Allah yang terbentang luas dalam alam semesta sebagaimana di firmankan oleh Allah : Ali-Imran: 190-191

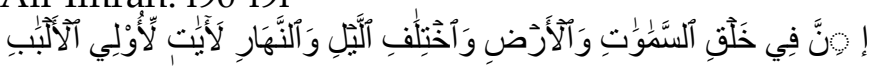

Sesungguhnya dalam penciptaan langt dan bumi, dan pergantian malam dan siang terdapat tanda-tanda (kebesar Allah) bagi orang yang berakal,(yaitu) orang-orang yang mengingat Allah sambil berdiri, duduk atau dalam kadaan berbaring, dan mereka memikirkan penciptaan langit dan bumi (seraya berrkata). "Ya tuhan kami, tidaklah Engkau menciptakan semua ini sia-sia; Mahasuci Engkau, lindungilah kami dari azab mereka.

Mereka percaya pula sepenuhnya kepada semua ayat yang diturunkan kepada Rasul-Nya. Apa yag tersebut dalam ayat-ayat itu adalah kebenaran mutlak yang tak dapat ditawar-tawar lagi.

'Sifat yang ketiga ialah memelihara kemurnian tauhid dengan benerbener menyembah Allah semata tanpa mempersekutukan-Nya dengan sembahan sembahan lain. Orang yang beriman tidak akan mau menyembah berhala-berhala atau minta tolong kepadanya, walaupun berhala-berhala itu dianggap oleh kaum musyrik sebagai alat untuk mendekatkan diri kepada Allah.

Sifat yang keempat ialah takut kepada Allah, karena mereka yakin akan kembali kepada-Nya pada hari berhisab di mana akan diperhitungkan segala amal perbuatan manusia. Meskipun mereka telah mengerjakan segala perintah Tuhan dan menjauhi segala larangan-Nya dan menafkahkan hartanya di jalan Allah, namun mereka merasa takut kalau-kalau amal baik mereka tidak di terima, karena mungkin ada di dalamnya unsur-unsur riya' atau lainnya yang menyebabkan ditolaknya amal itu. Oleh sebab itu mereka selalu terdorong untuk selanjutnya berbuat baik karena kalau amal yang sebelumnya tidak diterima, mungkin amal yang sesudah itu menjadi amal yang makbul yang diberi ganjaran yang berlipat ganda.

Dengan demikian, setiap dai dan orang-orang mukmin senantiasa takut kepada Allah akan segala amal perbuatannya mempunyai pertanggung jawabannya. Maka sudah seharusnya orang-orang mukmin agar selalu berhati-hati dalam semua tindakannya.

\section{Toleransi Agama}

Toleransi adalah suatu sikap yang saling menghargai, dan menghormati umat yang beragama satu dan beragama lainnya. Seorang juru dakwah hendaknya memiliki jiwa yang toleran, maksudnya bisa menghargai perbedaan keyakinan dalam arti tidak mengganggu keyakinan dan praktek ibadah di luar agamanya. Dalam ayat lain disebutkan untuk tidak mecerca sesembah lain sebab mereka akan berbalik mencerca Allah. 


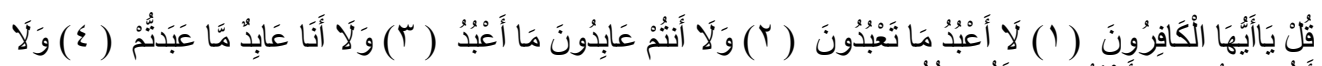

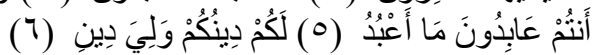

Artinya:Katakanlah, "Hai orang-orang kqfirAku tidak akan menyembah apa yang kamu sembah Dar? kamu bukan penyembah Tuhan yang aku sembah. Dan aku tidak pernah me'fjafh Penyembah apa yang kamu sembah, dan kamu tidak pemah mula) menjad: penyembah Tuhan yang aku sembah. Untukmu agamamu, dan untukkulah, agamaku. "

Maksudnya, terutama dalam masalah aqidah dan prinsip keyakinan agama. Sedangkan dalam masalah sosial demi mencapai kemaslahatan bersama ajaran Islam membolehkan untuk melakukan kerjasama seperti yang pernah dilakukan Nabi Saw di Madinah.

Namun demikian sikap menghargai juga bukan berarti seorang juru dakwah muslim bebas mengikuti cara dan praktek peribadahan orang lain, sebab kalau demikian adanya berarti ia sendiri mulai membuang identitas kemusliman yang seharusnya tidak terkotori.

\section{Tidak menghina sembahan non-muslim}

Islam melarang umatnya menghina atau mencaci penyembahan agama orang lain karena menghina adalah sifat manusia yang mengikuti hawa nafsu Ketentuan ini didasarkan pada Qs. Al-An'am: 108

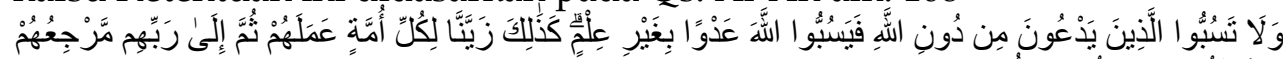

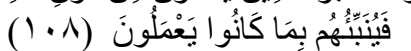

Dan janganlah kamu memaki sembahan-sembahan yang mereka sembah selain Allah, karena mereka nanti akan memaki Allah dengan melampaui batas tanpa pengetahuan. Demikianlah Kami jadikan setiap umat menganggap baik pekerjaan mereka. Kemudian kepada Tuhan merekalah kembali mereka, lalu Dia memberitakan kepada mereka apa yang dahulu mereka kerjakan.

Maksud ayat di atas Allah Swt melarang Rasul-Nya, Muhammad Saw dan orang orang yang beriman mencaci Tuhan kaum musyrikin, meskipun cacian itu mengandung kemaslahatan, hal itu menimbulkan kerusakan yang lebih besar dari pada kemaslahatan itu sendiri, yaitu balasan orang-orang musyrik dengan cacian terhadap Tuhan orang-orang mukmin, padahal Allah adalah Rabb, yang tiada ilah selain dia.

\section{B. Etika dakwah dalam Hadist}

Sedangkan Etika dakwah yang disebutkan dalam Al-Hadist sebagai berikut: 1. Mewarisi Tradisi Nabi SAW

"Abdullah bin Amr r.a. berkata: Nabi Saw bukanlah seorang yang keji perkataanmza, juga tidak biasa berkata keji, bahkan Nabi Saw bersabda: Sesungguhroza yang terbaik diantara kalian ialah yang terbaik akhlak budi pekertinya". (HR. Bukhari) ${ }^{15}$

15 Abdul Baqi, Dkk, Mutiara Hadits Shahih Bukhari Muslim. (Surabaya: Bina llmu : 2005), 
Seorang da'i bukan hanya menyampaikan pengetahuan praktis peribadatan, akan tetapi dalam konteks sosial ia juga berperan untuk menata moralitas perilaku masyarakat Islam dalam berbagai aspek kehidupan. ${ }^{16}$

a. Bermuka Manis dan murah senyum

"Sesungguhnya kamu tidak akan mampu meratai manusia dengan hartamu, tetapi yang dapat meratai mereka itu dengan muka manis dan perangai yang baik"

Dalam hadist ini seorang da'i dituntun memiliki perangai yang baik. bermuka manis dan murah senyum.

b. Merefleksikan Keimanan

Dari Abi Sa 'id al-Khudry r.a. saya mendengar Rasulullah SAW bersabda, barangsiapa melihat kemungkaran hendaknya ia ubah dengan tangannya, apabila tidak mampu dengan lisannya dan apabila tidak mampu juga dengan hati, sesungguhnya ini selemah-lemah iman (HR. Muslim, Ibn Majah, Annasa'i dalam kitab At-Targhib)

c. Nabi menganjurkan berbicara yang baik-baik saja

Sebutkanlah apa-apa yang baik mengenai sahabatmu yang tidak hadir dalam pertemuan, terutama hal-hal yang kamu sukai terhadap sahabatmu $\mathrm{m}$ sebagaimana sahabatmu menyampaikan kebaikan dirimu pada saat kamu hadir".(Ibnu Abi Dunya)

d. Tidak berperilaku sombong

“Dari Ibn Umar r.a ia berkata, bersabda Rasulullah saw, barangsiapa merasa besar diri, dan sombong dalam berjalannya, pasti ia akan menemui Allah dalam keadaan Allah murka kepadanya". Seorang yang dirinya berprofesi menjadi pendakwah harus mampu memelihara dirinya dari sifat sombong yaitu menolak kebenaran lantaran gengsi serta meremehkan manusia.

e. Tidak bermental hasud

"Dari Abu Hurairah r.a, bersabda rasulullah saw, jauhilah hasad sesunguhnya hasad itu memakan kebaikan seperti api melahap kayu baka (HR. Abu Daud)

Di antara penyakit yang tidak dianggap kecil dapat merusak citra dan profesionalitas da'i adalah hasud, hati merasa sedih jika melihat orang lain maju dan merasa gembirajika melihat orang lain sengsara/celaka.

f. Tidak mengadu domba

"Tidak akan masuk surga orang yang suka mengadu domba", "bukanlah termasuk mukmin orang yang suka mencela, melaknat, berperangai jelek dan kotor perkataannya ". Penyakit ini mungkin saja menghinggapi para da'I dan bisa merupakan kelanjtuan dari sifat hasud dan sombong. Karena hasud orang menjadi sering mengadu domba. ${ }^{17}$

\section{Simpulan}

Dakwah harus selalu dijalankan sesuai dengan kadar kemampuan setiap orang mukmin, yaitu adanya kesesuaian antara apa yang diucapkan

\footnotetext{
${ }^{16}$ Enianz AS dan Haiir Taiiri. Etika Dakwah, (Bandung: Widya Padjadjaran, 2009), h. 6

17 Ibid., h. 65
} 
dengan apa yang telah diperbuatnya. Dimana ucapan dan perbuatan tersebut mempunyai pertanggung iawaban di sisi Allah swt. Dakwah yang pada asalnya susah untuk diterima oleh jiwa orang-orang kafir, ketika disampaikan dengan cara yang buruk, cara yang kasar, tentunya justru akan membuat orang semakin lari dari kebenaran (dakwah). Oleh karena itulah, dakwah pada dasarnya harus disampaikan dengan cara lemah lembut. Dakwah juga senantiasa dilakukan dengan merasa takut kepda Allah swt bahwa kita senantiasa berada dalam pengawasan-Nya, Allah Maha Mengetahui akan segala sesuatu.

\section{Referensi}

Abudin Nata, Akhlak Tasawuf (Jakarta: Bulan Bintang, 1996)

Abdul Baqi, Dkk. 2005. Mutiara Hadits Shahih Bukhari Muslim. (Surabaya: Bina $\operatorname{llmu}$ )

Abu Zakaria Yahya bin Syaraf al Nawawi, Riyadhus Sholihin, (Surabaya: Al Hidayah l"I'im Penyusun Kamus Pusat Bahasa, op.cit,

Ahmad Amin, Etika Ilmu Akhlak, Cet. vm, (Jakarta: Bulan Bintang, 1996)

Ahmad Warson Mumwwir, Munawwir: Kamus Arab-Indonesia, (Surabaya: Pustaka Progresif; 1997)

Bukhari, Muhammad Ibn Isma'il Abu Abdullah. Sahih al-Bukhari. Juz 1, Beirut: Dar Ibn al-Kasir, 1422.

Departemen Agama RI, Al Qur'an dan Terjemahnya, Jilid 1O, (Jakarta: Departemen Agama RI, 2009)

Enjang AS dan Aliyudin, Dasar-Dasar Ilmu Dakwah, (Bandung: Widya Padjadjaran, 2009)

Hamzah Ya'qub, Etika Islam Pembinaan Akhlak aI-Karimah, CetJV, (Bandung: Diponegoro,1996)

Ibn Baaz, Abdul Aziz. Majmu Fatawa wa Maqolat Mutanawwiyah.

Ismail Ibnu Katsir, Tafsir Ibnu Katsir, Juz VII, (Mesir: Maktabah sh-Shofa, 2004)

Jafar, Iftitah. Tafsir Ayat Dakwah: Pesan, Metode, dan Prinsip Dakwah Inklusif.Cet. I; Makassar: Mishbah Press. 2010.

Mafri Amir, Etika Komunikasi Massa dalam Pandangan Islam, Cet. 1, (Jakarta: 1lmu. 1999)

Nabiry, Fathul Bahri. Meneliti Jalan Dakwah Bekal Perjuangan Para Da'i. Cet. I; Jakarta: Amzah, 2008.

Naisaburi. Gharaibul Qur'an wa Raghaibul Furqan. Bairut: Dar kutubil 'ilmiyah.

Qusyairi, Muslim Ibn al-Hajaj Abu al-Husain. Sahih Muslim. Juz 2, Bairut: Dar Ihya al-Turas al-Arabi.

Shihab, M. Quraish. Membumikan al-Qur'an. Cet. I; Jakarta: Lentera Hati, 2010. . Tafsir al-Mishbah: Pesan, Kesan, dan Keserasian al-Qur'an. Cet. 7; Jakarta: Lentera Hati, 2006.

Thabari, Abu Jafar. Jami' al-Bayan fii tafsir al-Qur'an . Jilid 14.

Tim Penyusun Kamus Pusat Bahasa, Kamus Bahasa Indonesia, (JakmtazPusat Bahasa,2008)

Tim Penyusun. Ensiklopedia Al-Qur'an: Kajian Kosa Kata. Cet. I; Jakarta: Lentera Hati. 2007. 